\title{
Influence of strategic transformation on the organizational structures of information services
}

\author{
Gerrida J. Oosthuizen* \\ Thabane College of Education, P.O. Box 5456, Rustenburg, 0300 Republic of South Africa
}

Adeline S.A. du Toit

Department of Information Studies, P.O. Box 524, Auckland Park, 2006 Republic of South Africa

asadt@info.rau.ac.za

Received July 1997; accepted August 1997

\begin{abstract}
Strategic transformation influences the organizational structures of information services. Organizational structures can no longer be used to predict and control the future and traditional methods should give way to innovation and creativity of staff. Successful strategies can only be implemented through an organizational structure that links people's abilities and skills to the mission of the enterprise. The key to efficient information services of the future is to reduce reliance on managerial authority, create teams that share information and delegate responsibility far down the hierarchy.
\end{abstract}

\begin{abstract}
Strategiese transformasie beïnvloed die organisasiestrukture van inligtingsdienste. Organisasiestrukture kan nie langer gebruik word om die toekoms te voorspel en te beheer nie en die tradisionele manier waarop personeel take verrig, moet plek mak vir innovasie en kreatiwiteit. Suksesvolle strategieë kan slegs geïmplementeer word deur 'n organisasiestruktuur wat die personeel se bekwaamhede en kundigheid koppel met die missie van die onderneming. Die sleutel tot doeltreffende inligtingsdienste van die toekoms is om die afhanklikheid van bestuursgesag te verminder, om werkspanne te skep wat inligting deel en om verantwoordelikheid laer af in die hiërargie te delegeer.
\end{abstract}

*Author to whom correspondence should be addressed.

Discontinuous change is one of the major characteristics of the South African environment at present and it necessitates an appropriate organizational response to survive - a transformation of the existing enterprise in terms of outer context (its external environment: clients, competitors, shareholders, suppliers, etc.) and inner context (its resources and its corporate culture). This implies that information services should be transformed to meet the information needs of clients within a rapidly changing and highly competitive society.

Organizational processes must be transformed to deliver the right response at the right time to highly unique and transient user needs. Faced with changing markets, advanced technology and increased competition, many information services have come to understand that the key to corporate success lies in transforming the way they function in terms of reducing reliance on managerial authority and delegating responsibility and accountability far down the hierarchy. Managers can no longer preserve their positions through hierarchies and structures, but need to respond to and challenge these rapidly changing forces by means of change.

Information services should structure themselves to minimize the impact of uncertainty. For tomorrow's information service, the rigidities of past structures are serious obstacles to flexibility, adaptability and quick response. They isolate the information service and its staff from the dynamics and immediacies of a fast-changing world which otherwise would compel them to engage in rapid and continuous learning. Traditional organizational boundaries, designed to keep everything in place with inflexible and narrow roles, must be replaced with structures that facilitate openness, fast and new responses to new challenges, and innovation to create the often 'elusive user-value' (Chattell 1995:173).

The modern information service should be re-organized for change with a structure that makes ample allowance for innovation and autonomy. Serious consideration should be given to relationships and interdependencies between employees as well as between the institution and its information users. The new structure should offer an information service which can determine clients' changing information needs and even offer various alternatives, including pro-active, assertive and collaborative approaches, which encourage continuous change and growth (learning).

Seen against the background of the short exposition provided above, the central question that will be addressed in this article is: why is it necessary for an information service to transform itself to fit the demands of the changing environment and what should the organizational structure of such an information service look like?

\section{Strategic transformation}

While the goal of all transformation is to improve performance, many efforts are not transformational. To qualify as corporate transformation, the majority of individuals in an enterprise must change their behaviour and develop new capabilities which demand extensive changes in how work gets done. Continuous improvement, innovation, learning and networking demand from employees a universal approach, co-operation with other enterprises, challenging managers and showing sensitivity for client needs. 
Phipps (1993:19) sums up the mission and transformation path of information services by stating that collection-centred enterprises should become access enterprises, from repositories of the printed format to enterprises less tied to place, paper and print. They should link clients to information and empower them to become self-sufficient information finders. The mission of linking clients to information is not changing but the means available to increase the success of this mission are changing drastically with the availability of electronic access. As such, the roles played by information specialists in the information services are becoming more pro-active, assertive and collaborative. The changing roles will require a commitment which in turn will demand personal and professional growth on the part of employees and a willingness to adapt to the future expectations of the organization and its clientele.

The information service of tomorrow is hypersensitive to user needs and integrates all its resources to function optimally and to deliver the right response at the right time. The challenge for information services is to adapt in ways that combine a focus on quality, cost and time reduction, changing user needs and the capacity to innovate and facilitate learning.

\section{Adaptability}

The ability to continue providing a service when conditions change is a good measure of organizational adaptability (Chattell 1995:13). Information specialists need to have a new type of flexibility which is more compatible with rapid technological change, new service techniques, and altered organizational structures. The information service of tomorrow is therefore transitory and should reflect the ability to design whatever structures, processes and services may be required to meet client needs.

\section{Innovation}

Experiencing the unexpected is the watchword of the information service of tomorrow, but being prepared for the unexpected increases the chances of handling it effectively. The most important objective of the transforming enterprise should be to grasp the new and discard the old. Successful innovation in enterprises has its source in people and managers who, rather than being dedicated to preserving positions, are dedicated to bringing about the future, and to apply new knowledge and ideas.

Innovation is about using technology to amplify people's achievements. The information service of tomorrow is an expression of what its staff can do which is different, creative and daring.

\section{Fast responses}

Information specialists need to be prepared and skilled enough to react fast to information requests. Services should match changing client needs with the ability to create and deliver them at the moment required. The development of just-in-time techniques is important to time-sensitive clients and simply means reducing the timelag between the identification of client needs and the creation and delivery of a customized response.

\section{Participative management}

An appeal has been made to information services to move away from specialized jobs to broader work responsibilities, away from narrow functional perspectives to an enterprisewide view (Transforming organisations 1992:154). In partial response to these demands, information services have set up cross-functional teams in areas such as new services and new process development. These teams are designed to respond quickly from a broad perspective and to do the tasks in parallel rather than sequentially. The main benefit is improved innovation and quality.

Leaders should create opportunities for employees to develop their abilities to make their fullest contribution and to deliver superior performances. Leaders of information services should create a shared vision among employees and only provide advice instead of command and control. This statement is often questioned, but is confirmed by Senge (1990:340) and Drucker (1988:49). According to Senge (1990:340), leaders should be designers of learning processes, serving staff rather than controlling them. Drucker (1988:49) says that an enterprise should be structured around goals that clearly state management's performance expectations for the enterprise and for each employee and around organized feedback that compares results with these performance expectations so that every employee can exercise selfcontrol. Employees should believe that their destinies are in their own hands. Challenges and problems, and not just predigested solutions, provide opportunities for individual growth. Information specialists must be given opportunities to solve problems and to make decisions when necessary. They must be seen as experts in their fields of knowledge and they must be seen and treated as the primary assets of the institution they serve.

\section{Organizational learning}

Zuboff (in Peters 1993:382) states the following:

'Learning is the new form of labour. It's no longer a separate activity that occurs either before one enters the workplace or in remote classroom settings ... learning is the heart of productive activity'.

Information specialists frequently learn from their clients and colleagues. Today the emphasis is on knowledge integration. Knowledge only becomes productive when integrated into a task or applied in a meaningful way.

\section{Role of leadership in the transformation process}

Beer, Eisenstat and Spector (1990:159) suggest that the change process be introduced at the periphery of the enterprise and not at the top. Leadership plays an important role, namely one of specifying the direction of change without insisting on specific solutions. The main purpose is to align 
employee roles, responsibilities and relationships to the mission or the problems to be solved. Innovative actions should come from employees close to the action. Employees must be put into new roles, responsibilities and relationships. Once new management practices have been developed at the periphery, the enterprise's structure and systems must be aligned with the practices to ensure enduring transformation.

Management's leadership of the change effort seems to be the key determinant of whether the change effort will succeed or not. This new type of leadership will have to do more than merely creating and articulating a new vision for the information service (Clement 1994:33). Specific leader behaviours are necessary, for example communicating openly, widespread participation by making decisions in teams and demonstrating visible and consistent support for change.

According to Beer, Eisenstat and Spector (1990:158), the best leaders hold their subordinates responsible for starting the change process. Eventually, however, all managers must adopt the team behaviour, attitudes and skills that they have demanded of others in earlier phases of change, otherwise the whole process of change will fail.

Managers of the information service should motivate people, rather than simply tell them what to do. The skills needed for such a role are largely those associated with consultancy work, listening and communicating (Beck 1989: 26). De Coning (1994:35) describes the task of a true transitional leader as follows: to crack down on unnecessary bureaucracy and to empower followers to pro-actively identify and exploit new opportunities on behalf of the enterprise. This leadership function includes:

- Formulating and testing visions for the enterprise.

- Being a proper entrepreneurial role model for followers.

- Being tolerant of followers' mistakes.

- Continuously coaching and mentoring followers.

- Establishing and maintaining a culture conducive to entrepreneurship.

\section{Creating entrepreneurial structures}

In the face of rapid change and growing environment complexity, traditional authoritarian bureaucracies are becoming what Kreitner (1983:237) calls 'unwieldy structural dinosaurs'. For the information service of tomorrow, the structures of the past are obstacles to flexibility, adaptability and fast responses. Outdated organizational structures are no longer conducive for predicting and controlling the future. New leaders are needed to seek positive outcomes and results through any possible and flexible configuration of resources.

In the old paradigm, most enterprises spent most of their time managing weaknesses instead of realizing and amplifying the potential of those resources with most to offer. Professional and technical skills are of no value unless their owner is empowered to make an integrative and creative contribution towards customer value.

Every organizational system has a structure that, according to Andrews and Herschel (1996:131), serves three basic functions. First, it helps to produce organizational output and to achieve organizational goals. Second, structure helps to minimize or at least regulate the influence of individual variations on the enterprise. Lastly, structures are imposed to ensure that individuals conform to the requirements of enterprises and not vice versa. According to Hill and Jones (1989: 223), strategy can only be implemented through organizational structure. They stress that the activities of organizational personnel are meaningless unless some type of structure is used to assign people to tasks and to connect the activities of different people or functions. Reese (1994:70) sees structure as a mechanism binding the specialized functions of an enterprise to a common purpose.

From the above views, it is clear that a well-designed structure provides a framework for effective management and is a subject that managers of information services should pay serious attention to. A muddled, unorganized enterprise wastes labour efforts, is slow to respond to opportunities or threats and unpleasant to work in.

\section{Designing organizational structures}

Organizational design means choosing the best type of structure for a given situation. It is a continuous process because environments, enterprises and strategies change over time. Large changes in organizational structure may be required occasionally and smaller changes may be needed more often. Like many complex managerial issues, the problem of organizational design may never be permanently resolved because of the changing environment.

To design a structure, decisions must be made on the differentiation and integration of people, tasks and technology. People and resources must be allocated to organizational tasks and decision-making authority must be distributed effectively. The resources and people need to be co-ordinated to achieve organizational goals. In short, differentiation refers to the way in which an information service divides itself into units, and integration refers to the way in which the units are then combined towards a common goal. Together, the two processes determine how an organizational structure will operate and how successful managers will be in implementing their chosen strategies.

The most discussed debate in organization theory concerns the question of what determines structure. Five determinants and the conditions under which each can become the major cause of an information service's structure are discussed, that is strategy, size, technology, environment and power and control.

\section{Strategy}

Strategy has a direct impact on structural design. It has to do with management's assessment of environmental uncertainty. According to Miles and Snow (1978:21), managers can select a defender strategy, a prospector strategy, an analyser strategy or a reactor strategy. An information service's structure should fit the chosen strategy. Defenders seek stability and strive aggressively to prevent competitors from entering their 
domain - defenders perceive the environment as stable. Prospectors are almost the opposites of defenders. They exploit all opportunities coming their way and therefore invest a lot in scanning the environment. Analysers try to capitalize on the better of the two preceding types. They seek to minimize risk and maximize opportunity for profit. Their strategy is to move into new services only after viability has been proven by prospectors. Prospectors consider the environment as dynamic while analysers see it as changing. Defenders will opt for tight control, analysers for moderately centralized control while prospectors will have a loose, flexible structure that is decentralized with a low degree of formalization. Reactors are enterprises whose strategies are inconsistent or ill defined. Reactors may respond inappropriately to environmental change. Reactors may also be enterprises responding so frequently to environmental changes that they cannot be identified as any of the other three strategy types.

\section{Size}

Since it is people and their interactions that are structured, size can be seen as the total number of employees in an enterprise. If top management is far removed from operating levels because of vertical differentiation, senior managers will find it difficult to make rapid and informative decisions. Larger information services are more highly differentiated and more formalized than smaller information services. Increased size makes decentralization necessary and is less bureaucratic but more formal. According to Andrews and Herschel (1996: 135), size is more likely to be an outcome than cause of structure. The relationship between size and structure is not clear yet. Once an enterprise becomes large in size, it tends to be high in complexity and formalization and more decentralized. Enterprises should keep their units small to maintain flexibility and responsiveness to change (Robbins 1990:161).

\section{Technology}

According to Robbins (1990:185), the more routine the technology an enterprise uses, the more highly structured the enterprise should be. Conversely, non-routine technologies require greater structural flexibility, would be decentralized, have high interaction among all members with a minimum degree of formalization, and problem solving is done by those with the greatest knowledge and experience.

In the case of information services that function in highly automated environments and employ experts with specialized knowledge and skills, non-routine technology is applied most of the time. As services become more individualized, and customized, the span of control narrows and vertical differentiation increases. Thus greater use is made of specialists who offer a non-programmed variety of services. Routine technologies are associated with a centralized structure applying formalized procedures. Non-routine technologies are characterized by delegating decision-making authority to specialists who make their own decisions.

\section{Environment}

Structural design is a major tool of controlling environmental uncertainty. The environment is seen as everything outside the boundaries of an enterprise that affects the organizational structure and managerial practices in an enterprise. Burns and Stalker (in Robbins 1990:211) reveal that the type of structure that exists in rapidly changing environments differs significantly from those in enterprises with stable environments. Enterprises must adapt to changes in their environment to maintain or increase their effectiveness. Different enterprises face different degrees of environmental uncertainty and the more diverse the environment, the more bridging techniques enterprises employ to adapt.

\section{Power and control}

An enterprise's structure, at any given time, is to a large extent the result of a selection that those in power have made to maintain and enhance their control to the maximum. Andrews and Herschel (1996:127) agree that those with power in an enterprise decide on what is considered organizational issues. They make the strategic choices with regard to the enterprise and its structure, select strategies and technologies for implementing them, and arrange roles and responsibilities to effectively use and co-ordinate the technologies employed. Just as they choose objectives, personnel or control techniques, managers also choose the enterprise's structural design.

\section{Adhocracy}

Adhocracy represents a group of professionals working together in a team for a singular purpose with no entrenched hierarchy, no permanent departments, no formalized rules or standardized procedures. Communication between employees of different ranks tends to resemble horizontal consultation more than vertical command. It is characterized by decentralization and great flexibility and responsiveness. The need for supervision is minimal because professionals have internalized the behaviours that managers want. When faced with a problem, some standardized programme is used to treat or solve it in a uniform manner. The technostructure in the adhocracy is almost non-existent because typically all middle managers, support staff and operatives are professionals. Power is vested in anyone in the adhocracy with expertise, regardless of his/her position.

Specialists are grouped together in flexible teams with a few rules and guidelines. Different department members can be deployed into small teams which cut across functional units and perform towards a common goal. Teams can exist for a day, a month or a year. Roles performed are interchangeable, depending on the nature and complexity of the mission. The co-ordination of diverse specialists to facilitate rapid response and innovation is now possible.

Adhocracy requires top management to release some of its control. The matrix structure is the most popular example of adhocracy. Employees in the matrix have two overseers, namely a funtional department manager and a project or team 
leader. The project manager has authority over project employees relative to the project's goal only. Departments are becoming interdependent in response to demands from the environment. The direct and frequent contact between different specialists in the matrix improve communication and flexibility.

\section{Case study: Academic Information Service, Univer- sity of Pretoria}

The Academic Information Service of the University of Pretoria has experienced an interesting and dynamic period of organizational development since 1975 under the leadership of its director, Prof. E.D. Gerryts. The transition process at this institution took place in two phases. The first can be called an organizational development phase, which started in 1975 and ended in 1990, and the second, which developed from the first, an organizational transformation phase, which is, at the present phase of development, designing a competency-based compensation system.

The path of organizational development at the Academic Information Service, during the period 1975-1990 was characterized by four projects. These projects were aimed at specific objectives which would ensure an acceleration towards organizational maturity and also reflect a five-year planning cycle. A full description of phase one is found in Gerryts (1991:167-184). During this phase the output of strategic planning exercises indicated that the organizational structure of the information service would not meet the new challenges effectively. The role of top management had to be reconsidered and a system of participative management was introduced. The functional organizational structure could not accommodate an enterprise which experienced a growing professional maturity. The long lines of vertical communication through middle management caused delays in decision making.

The question was how to end the long tradition of a functional organizational structure. This question and many more led to a workshop in 1990 attended by senior members of staff. This was the start of a strategic transformation process. During the break-away session, scenarios for the following five and ten years were sketched. It was found that the information service would not at all be in a position to handle the expected needs satisfactorily and that the hierarchical functional organizational structure would not pass the test of the near future. All members of staff attending the workshop agreed that fundamental change would be necessary if the winning edge, enjoyed at that stage, was to be maintained.

The new organizational structure embodies the transformation from a hierarchical to a matrix structure. The matrix structure simultaneously provides a co-ordination mechanism and a means to manage diversity. It offers a means of counteracting a hierarchical structure that limits innovative behaviour. The various faculties are served by different service units. Each service unit has its own budget, according to the needs of its clients. The leaders of the various service units work together to solve problems. All activity is taking place towards a shared vision, namely to develop an Afrocentric information model that optimally supports clients from developing communities who have a need for worldwide information resources. This organizational structure provides better accommodation for project management and task forces and for the flexible utilization of human resources. The change from a hierarchical structure to a matrix structure has meant a transformation regarding structural and power relationships (Gerryts 1995:57-72).

During a visit to the United States of America in 1992, the director realized that a strategic framework was required to guide the information service to a preferred future position. The strategic framework for the information service, as discussed and formally approved by the University, entails the following (Gerryts 1996):

- A mission statement, containing marketing orientation, mission success factors and key values.

- A vision and value system.

- Strategic tendencies in the academic information society and information business, referring to the role of authors, publishers and information brokers.

- Products and services for various client groups and marketing segments.

- A marketing strategy, to be revised continuously.

- A strategy for managing information sources as a resource, switching from a paper-driven approach to an electronic-driven approach.

- A strategy for managing information systems and technology.

- A strategy for managing human resources.

- A strategy for managing space (facilities).

- A strategy for managing finances with a market-driven approach.

- A strategy for organizational transformation.

- A strategy for control, dealing with aspects such as commitments, alignment and empowerment.

- A strategy for a comprehensive plan to ensure the availability of resources required to move to the preferred position.

The strategic framework confirms that the information service is determined to shape its own future. Organizational transformation at the Academic Information Service of the University of Pretoria brought a new perspective on the meaning of success. Success is seen as the result of a vision of the future. By flattening the structure, decision making is taken to the point where the problem occurs. Furthermore, there is a vision of what clients can expect of the information service in the future, namely that the new organizational structure will shorten communication lines and one-stop service units will be provided. In a cost-effective service, the focus is on access rather than ownership. The transformed information service is characterized by:

- Lateral relationships replacing hierarchy.

- Alliances, partnerships and close co-operation with clients, brokers and competitors. 
- More staff involvement and less control.

- Learning as part of organizational functioning.

- Change as a continuous process.

- A shift of emphasis from management to leadership.

In short, the emphasis is no longer on doing things right, but on doing the right things to ensure that the information service moves effectively through the change process towards its preferred future position.

\section{Discussion}

As the new millennium nears, there is no doubt that technology is shrinking the information gap which used to exist between the information required and the information easily and practically available. In future, information services will have a more distributed structure with integrated electronic work stations providing support, access and value-added services to clients.

Drucker (1992:95) and Peters (1992:103) both agree that tomorrow's enterprises are going to be flatter, less hierarchical and more decentralized. In one word, they will be more adhocratic. A group of professionals will be working together as a team with no entrenched hierarchy, no permanent departments, no formalized rules or standardized procedures. According to Peters (1992:102) management will create flexible, porous, team-based enterprises. Written rules will be replaced by a strong competitive vision and by managers who lead by example. Benton and Lloyd (1992:116) see the key challenge for any enterprise as being able to keep the responsibility at the top while effectively delegating authority for action further down.

It is time for a new model of information services and information specialists. Information specialists must view themselves not as custodians or even as providers of centralized expertise, but rather as overseers of multimedia networks (Davenport \& Prusak 1993:412). They must be concerned with the structure and quality of the content that goes out over the network, the format in which it is distributed, and the audience to whom it is directed, as well as how the receiver will respond to it. Broadly speaking, the role of the information specialist becomes one of establishing connections between those who have and those who want information. The information service must be viewed as a virtual information network that provides access to internal and external information resources of which many are now available in electronic format.

The forthcoming period of change should be characterized by the transition from the physical information service to the logical information service (Gerryts 1995:61). Managers of information services should realize that people, not printed or electronic sources, are the most valuable information assets in any enterprise. The old model of information specialists who guarded the stacks from information users, or of researchers and academics who browsed in comfortable reading rooms, will never be appropriate again.

As information technology alters the information service's environment, managers are trying to work within shifting organizational structures. Information services are undergoing internal transformation within their technical procedures, work flow and assignment of personnel. Online systems integrate many functions, obscuring divisions between public and technical service operations, and breaking down traditional barriers. Task forces and project committees are emerging as information services start to adopt a form of matrix management consisting of temporary groups that cut across traditional boundaries to make decisions and solve problems. There is a tendency for greater power equalization between staff and increased participation. Work is largely done by task-force teams or groups from the stage of research to service establishment in the market.

The hierarchical structure is flattening and technical and public services are finding themselves reporting to the same manager. According to Drucker (1988:45), the typical large enterprise 25 years hence will have fewer than half the present levels of management and no more than a third of the managers. The business of the future will be knowledgebased, composed largely of employees who will direct and discipline their own performance through organized feedback from colleagues, customers and leaders. Automation will introduce new organizational ties with outside enterprises which will cut across departmental lines within the enterprise and become primary sources of information on the specific environmental area.

The key to competitive success is to reduce reliance on managerial authority, formal rules and procedures, and narrow divisions of work and to create teams that share information and delegate responsibility far down the hierarchy. In the information service of tomorrow, each employee will be judged by his/her contribution to the common task rather than by any inherent superiority or inferiority. Therefore, the modern information service cannot be one of overseer and subordinate, it must be organized as a team that does its own work, moved by a common goal. Leaders are only responsible for the information service's mission, its spirit and performance. Their job in the modern enterprise is not to command but to inspire.

Managers must begin to change the ways in which decisions are made and they should explore organizational structures that allow broader involvement by staff. Managers should be willing to assume calculated risks to realize the vision of tomorrow's information services (Personnel administration ... 1990:110). They will have to be willing to anticipate challenges and devise creative strategies to meet them. Cross-training of employees and temporary exchanges between staff of different work units will broaden job knowledge and improve job satisfaction. In shaping the future and changing the vision, information specialists will see themselves as learners. They will be dynamic in the information business, will encourage continual change and growth and strive towards flexibility and adaptation. Designing jobs to increase productivity and maintain employee satisfaction will be a major challenge for managers of information services. 


\section{Conclusion}

From the above discussion, the following important conclusions can be drawn:

- Change is a continuous process, not only structural but also in purpose and process, and in the way people operate.

- The personnel is the most valuable resource of any enterprise (including information services) and should be given the opportunity of developing and participating in decision making. Staff members can only make a unique contribution towards decision making if they are multiskilled, trained and motivated.

- Hierarchy is replaced by flatter organizational structures that make provision for lateral relationships, more independence, decentralized activity, close contact with clients, and more autonomy with co-responsibility.

- Visionary leadership is needed for effective transformation. Only through shared decision making can consensus be built and alignment be generated towards a preferred future position.

- Learning should be part of organizational functioning. As part of the learning process, experimentation and risk taking should be encouraged and mistakes recognized, accepted and rectified. New ideas and better approaches should be investigated in the search for unique and excellent solutions.

\section{References}

Andrews, P.H. \& Herschel, R.T. 1996. Organisational communication. Boston: Houghton Mifflin.

Beck, M. 1989. Learning organisations - how to create them. Industrial and commercial training, 21(May-June):21-28.

Beer, M., Eisenstat, R.A. \& Spector, B. 1990. Why change programs don't produce change. Harvard business review, 90(6):158-166.

Benton, P. \& Lloyd, B. 1992. Riding the whirlwind: managing turbulence. Long range planning, 25(6):111-118.
Chattel, A. 1995. Managing the future. London: MacMillan.

Clement, R.W. 1994. Culture, leadership and power: the keys to organisational change. Business horizons, Jan-Feb:3-39.

Davensport, T.H. \& Prusak, L. 1993. Blow up the corporate library. International journal of information management, 13(6):405412.

De Coning, T.J. 1994. Strategic transformation: opportunities for the information services industries. South African journal of library and information science, 62(1):34-37.

Drucker, P.F. 1988. The coming of the new organization. Harvard business review, 66(1):45-53.

Drucker, P.F. 1992. The new society of organisations. Harvard business review, 92(5):95-104.

Gerryts, E.D. 1991. Managing organisational development in the modern university library environment. IATUL quarterly, 5(3):167-184.

Gerryts, E.D. 1995. Organisational transformation. IATUL proceedings, 4:57-72.

Gerryts, E.D. Director, Academic Information Service, University of Pretoria. 1996. Personal interview, October.

Hill, C.W.L. \& Jones, G.R. 1989. Strategic management: an integrated approach. Boston: Houghton Mifflin.

Kreitner, R. 1983. Management. 2nd ed. Boston: Houghton Mifflin.

Miles, R.E. \& Snow, C.C. 1978. Organisational strategy, structure and process. NewYork: McGraw-Hill.

Peters, T. 1992. Liberation management. London: MacMillan.

Phipps, S.E. 1993. Transforming libraries into learning organisations - the challenge for leadership. Journal of library administration, 18(3/4):19-37.

Reese, K. 1994. Managing the corporate future. Halfway House: Southern Books.

Robbins, S.P. 1990. Organisational theory: structure, design and applications. 3rd ed. New Jersey: Prentice Hall.

Senge, P.M. 1990. The fifth discipline: the art and practice of the learning organization. New York: Doubleday Currency.

Transforming organisations. 1992. Edited by T.A. Kochan \& M. Useem. New York: OUP. 